15. Zelenska, O. (2006). Linhvistychni osoblyvosti movy anhliiskoho yurydychnoho tekstu. Visnyk: Problemy ukrainskoi terminolohii. Lviv: Vyd-vo NU «Lwivska politekhnika», 559, p. 222-226.

Матеріал надійщов до редакиіï 10.01.2021 p.

\title{
УДК $81^{\prime} 373.23 ’ 42:[32: 316.658$
}

\section{Ніна Печко,}

кандидат філологічних наук, доцент кафедри іноземних мов та перекладу, Волинський національний університет імені Лесі Українки, ORCID ID 0000-0001-6084-8693

pechko.nina@vnu.edu.ua

DOI 10.29038/2524-2679-2021-01-148-160

\section{ІНТЕРПРЕТАЦІЯ ІМПЛЦЦИТНОЇ СЕМАНТИКИ АНТРОПОНІМІВ ПОЛІТИЧНОГО ДИСКУРСУ}

У статті досліджено імпліцичтний аспект політичного дискурсу через аналіз семантичних імплікатур антропонімів політичного дискурсу. Останні включають офіційні (імена, прізвищуа) та неофіційні (прізвиська, прізвиськові утворення, псевдоніми) найменування відомих політичних діячів, глав держав й урядів та є одиницями первинної та вторинної номінації, щзо визначає різні підходи до їх вивчення та шляхи інтерпретації семантичних імплікатур, які вони репродукують. Визначено, щзо під час дослідження офіційних найменувань політичних лідерів найбільш дієві етимологічний $і$ семасіологічний підходи. Саме вони дають змогу простежити походження конкретного антропоніма та виокремити імпліцитні семантичні елементи шляхом аналізу значення його дериваційних складових частин. Семантичне значення таких ономастичних одиниць с специифічним: воно не відбиває понять, а лише вказує на первісну семантику -мотиви номінації. Такі семантичні імплікатури, зазвичай, є безвідносні до персони номінанта, особистісно невмотивовані, почастумістять нейтральнупозалінгвальнуінформацію. При цзьому вони є невід'ємними елементами цілісного семантичного значення антропоніма.

Доведено, щзо вивчення неофіџійних антропонімів політичного дискурсу вимагає застосування прагматичного підходу, оскільки утворення прізвиськ $i$ прізвиськових утворень зумовлене екстралінгвальними

(C) Печко Н., 2021 
чинниками, є прагматично та функиіонально вмотивованим. 3'ясовано, щуо семантичні імплікатури таких неофійних найменувань містять позитивну й негативну конотації та в гіперболізованому вигляді вказують на характерні особистісні риси номінанта, виокремлюють його з-поміж інших, ретранслюють інформацію про специифіку й основні моменти його політичної кар'єри.

Ключові слова: політичний дискурс, номінація, офіційний антропонім, неофіиійний антропонім, прізвисько, семантична імплікатура.

\section{1. ВСТУП}

Постановка проблем. Політичний дискурс як складна їєрархічна система характеризується низкою відмінних факторів/ особливостей, серед яких чільне місце посідають імплікативні елементи, що продиктовано власне його функціональною спрямованістю. Остання може визначатися як така, що впливає на масову свідомість, мотивує до формування певних уявлень та оцінних позицій, вербально спонукає до реалізації конкретних дій тощо. Успіх комунікації, зокрема в політичному контексті, залежить від уміння ефективно розпізнати та зіставити всі комунікативні елементи дискурсу, експліцитні та імпліцитні, об’ єднати їх у кінцевий завершений продукт - ментальну модель повідомлення. Відтак не можна обійти увагою семантичні імплікатури, які формують значну частку інформаційного поля політичного дискурсу.

Аналіз останніх досліджень. Ідея дослідження імпліцитних елементів дискурсу повсякчас викликала жвавий інтерес як вітчизняних, так і закордонних лінгвістів. Це зумовило низку продуктивних лінгвістичних розвідок із цієї проблематики. Зокрема, базовим уважається виокремлення конвенційних та комунікативних імплікатур Г. Грайса, стратегій інтерпретації дискурсу ван Дейка, вивчення значущості імпліцитної інформації та інференційних процесів (Л. Р. Безугла, О. М. Кагановська, R. Carston, J. L. Hamblin, J. Hobbs, D. Wilson).

Аналізуючи політичний дискурс, дослідники мало звертають уваги на ще один імліцитний елемент політичного дискурсу - семантику антропонімів, тобто імен, прізвищ, прізвиськ політичних лідерів, глав держав, відомих політичних діячів. А дарма, оскільки семантична складова власних назв політичних лідерів, яка містить позалінгвальні пресупозиції процесу називання та психолінгвістичний статус неофіційних найменувань, може стати додатковим джерелом інформації щодо певної особистості, мотивів ㄲï поведінки, психологічних 
характеристик та навіть розкрити особливості ऑiі комунікативних стратегій і тактик.

Мета статті - здійснити аналіз семантичних імплікатур антропонімів політичного дискурсу, зіставити конотативне значення офіційних власних назв політиків і їхніх неофіційних найменувань.

\section{2. РЕЗУЛЬТАТИ ДОСЛІДЖЕННЯ}

Природа терміна «дискурс» настільки багатогранна, що, незважаючи на досить довгу історію його дослідження й численні праці у сфері дискурсивного аналізу, говорити про однозначне розуміння дискурсу вважається передчасним. Прихильники діяльнісного підходу трактують дискурс як соціальне конструювання реальності та форму вияву знань. Політичному дискурсові притаманний не лише смисл, а й суб'єктивне зіставлення з певною групою людей. Різні суб'єкти спілкування по-різному відображаються в дискурсі: комунікативні форми породжують власний зміст [1, с. 186-187] .

За останні роки політичний дискурс став активним об'єктом лінгвістичних досліджень. Під політичним дискурсом розуміємо зв'язаний текст, зумовлений ситуацією політичного спілкування в сукупності з прагматичними, соціологічними, психологічними та іншими факторами. Значущими є всі наявні компоненти дискурсу - лінгвальні та екстралінгвальні, - які сукупно формують єдину змістову модель. Семантика політичних антропонімів $є$ однією з таких складових частин.

Лінгвісти вказують, що семантичне значення антропонімів, як $\mathrm{i}$ інших власних назв, є специфічним, оскільки не відбиває понять. Можна говорити лише про первісну семантику антропонімів, тобто про мотиви та принципи номінації. У цьому контексті варто згадати про існування декількох підходів до класифікації прізвищ із погляду лексико-семантичної бази. Зазвичай, виокремлюють етимологічний (М. Бірила), соціологічний (Я. Бистронь), історико-функиіональний (С. Бевзенко, М. Демчук), синхронно-діахронний (О. Добровольська, Ю. Карпенко, Р. Керста, Р. Осташ) та інші підходи. Наприклад, В. Никонов, аналізуючи прізвища із семантичного погляду, розподіляє їх на шість груп: патронімічні, прізвища належності, власницькі, земляцькі, церковні й прізвиська. В основу такої класифікації покладено дериващійний принщии [2, с. 21].

Стратифікація суспільства на різні соціальні групи та верстви населення віддзеркаюється в лексиці, номінативних елементах, зокрема таких, як прізвиська, що є неофіційними антропонімами. Вони є соціально та 
політично вмотивованими, а також особливо насичені екстралінгвальною інформацією. Таким способом суспільство маркує індивідумів, виокремлюючи соціальний, майновий, професійний, рольовий статус іменованих на своєрідній ієрархічній драбині; створює враження про людину [3, с. 209]. Прізвиська є соціальними антропонімами (Т. Денисова) й водночас оцінними найменуваннями, які прямо чи непрямо відображають статус особи в суспільстві та його суспільну оцінку [4, с. 159].

Методи дослідження. Із метою аналізу політичних антропонімів i їх семантичних імплікатур потрібно здійснити певне розмежування аналітичних підходів залежно від офіційного чи неофіційного статусу цих номінативних одиниць. Політичні антропоніми офіційного штибу варто розглядати з позиції етимологічного та семасіологічного підходів, що дасть змогу простежити значення антропоніма через ретрансляцію його первинного значення як загальної назви чи значення його окремих складників. Щодо аналізу неофійних політичних антропонімів дієвим вважаємо прагматичний nidxid, що дасть змогу виокремити комунікативну спрямованість таких назв, їх перлокутивну вмотивованість й екстралінгвальне підгрунтя.

Отже, великий прошарок офійних політичних антропонімів становлять імена та прізвища відомих політиків, політичних діячів, глав держав й урядів, очільників міжнародних організацій тощо. Проаналізуємо деякі 3 них. Наприклад, лексема trump (за прізвищем американського президента Д. Tpamna) має багато трактувань і значень із різною конотативною оцінкою. Зокрема, у якості дієслова вона означає здобути перевагу, домінувати, перевериити. У загальному глосарії іменник trump має значення славний пацุан. Семантика цієї ж лексичної одиниці в австралійському слензі дещо відрізняється, там truтр - це начальник, шеф, бос, людина, котра має владу. Цікавим є також ще одне семантичне значення цієї лексеми - козир, козирна карта. Як бачимо, семантичні імплікатури цього антропоніма - розв 'язність, зверхність, владність, авторитарність - чітко прослідковуються та логічно збігаються з особистісними характеристиками сорок п'ятого президента Сполучених Штатів [5].

Цікаво трактують прізвище президента Росії Володимира Путіна. Існують два основні напрями - тлумачення номінації, грунтуючись на позитивній і негативній конотації. Вочевидь, простежуємо вираження думок прихильників та противників цього політичного лідера i яскраву ідеологічну складову частину. Перша версія 3 позитивною конотацією пропонує таке тлумачення: походить від рос. nymb або англ. put in та означає - 'той, хто прокладає шлях'. Версія з негативною конотацією: Путін 
- походить від російського слова пута або путина та означає в'язнути, грузнути, занурюватись. Існує також версія, що цей антропонім походить від чеського слова putina та означає - 'хаос' або 'той, хто творить хаос'[6].

Зауважимо, що існує зворотний процес, а саме власні назви окремих діячів дають поштовх до творення нових лексичних одиниць і стають політичними неологізмами. Так, шляхом конверсії власної назви Меркель 3'явилося новоутворення merkeln - меркелити (2015), яке набуло широкого вжитку в молодіжному сленгу Німеччини. Його значення - нічого не робити, сумніватися, бути нерішучою, відкладати рімення в довгий ящчик.

Значення прізвища Порошенко залежно від його дериваційних складників, теж має декілька трактувань. Вважається, що цей антропонім походить від лексеми пороша, що означає пухкий сніг, переважно перший або який щойно випав [7]. Опираючись на етимологічний компонент, визначаємо, що Порошенко - прізвище, що має дуже давнє походження від народу бродників, який існував на Причорномор'ї у

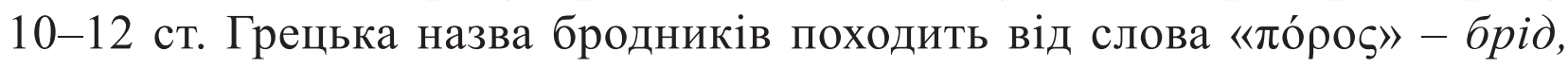
шлях, переправа. Від цього ж слова походить український префікс «про-» (у словах прохід, проїзд, проникнення, прокол), слово «пора» (отвір у чомусь) і слово «подорож». Порох - брід, Порошенко - людина з бродників (Микола Сирота). За однією з версій, бродники - колишні жителі занепалих князівств Тмутаракані та Білої Вежі, які з приходом половців були витіснені на захід, а після вторгнення монголів стали васалами Золотої Орди, отримавши землі сучасної Молдови й Нижнього Подунав'я. Саме тут, до речі, і спостерігається найвища концентрація прізвища Порошенко [8]. Прикметно, що політичний лідер із прізвищем Порошенко, котре містить семантичні імплікатури перехід, зміна ma шлях, очолював наша державу в непростий період конфронтації 3 Російською Федерацією, водночас зумів добитися низки поступок та преференцій від Євросоюзу, а також реалізувати ідею безвізового режиму для українських громадян.

Етимологічне походження політичного антропоніма Зеленський має декілька трактувань. За першою версією, прізвище Зеленський утворене від власного імені та належить до поширених українсько-польських прізвищ. Основою його вважається нецерковне ім'я Зеленій. Цілком імовірно, що в цей онім укладено особливий сенс, пов' язаний із символікою зеленого кольору, який в уявленнях багатьох народів уособлював весну, дозрівання, родючість, воскресіння, життя. У стародавні часи вислів «вічнозелений» означав безсмертя, як похідне від суміші жовтого (землі) та синього (неба) (цікаво, що аналогічні кольори є складовими частинами 
українського прапора). Тому ім'ям Зеленій часто колись називали малюків. Разом із тим лексема зелений має й негативну конотацію, адже зелений це колір незрілості. Людина 3 таким найменням асоціювалася 3 особою недосвідченою або такою, котра не досягла певного віку [9]. Прикметно, що політична діяльність та особистісні характеристики нинішнього Президента України з прізвищем Зеленський відзеркалюють ті семантичні імплікатури, котрі містить цей антропонім. 3 одного боку, це надія виборців на воскресіння держави та початок нового кращого життя (імплікатура 3 позитивною конотацією), а з іншого - дається взнаки політична незрілість та нестача досвіду роботи на державницьких посадах (імплікатура 3 негативною конотацією).

Цікаво також проаналізувати імпліцитну семантику прізвища нинішнього президента Сполучених Штатів - Джо Байдена. Основу цього антропоніму становить лексема to bide. Це дієслово може бути перехідним та неперехідним і має декілька значень. Так, за словником Merriam-Webster перехідне дієслово to bide означає 1) чекати, очікувати та найчастіше трапляється у вислові bide one's time (очікувати вдалого моменту, чекати на свій час); 2) вистояти, пережити (bide the winter storm); 3) миритися, терпіти. Вочевидь, наявні семантичні імплікатури мають позитивний зміст для 46 президента Сполучених Штатів Джозефа Байдена, якому доведеться долати чимало різних викликів [10].

Звернемося до аналізу неофіційних антропонімів політичного дискурсу, цебто прізвиськ знаних політиків та глав держав. У сучасних лінгвістичних студіях дефініція терміна прізвисько охоплює мотиваційні та функціональні ознаки, закладаючи таким чином основи прагматичного підходу дослідження цих неофійних найменувань. Прізвисько трактується як неофіційне найменування, яке дають номінатори особі чи колективу людей за індивідуальними ознаками, а також за спорідненістю і свояцтвом між носієм і членами родини для ідентифікації та конкретизації. Прізвиськам притаманні індивідуальність, конотативне забарвлення й умотивованість (М. Наливайко) [11].

Увівши поняття моделі, О. Суперанська дещо розширила спектр неофіційних антропонімів, зазначивши, що «Якщо ім'я відповідає моделі, воно сприймається як ім'я. Якщо воно за якимись параметрами (асоціаціями 3 апелятивами) не задовольняє ці моделі, структура його порушується і є причини говорити про прізвиськові утворення» [4, с. 189]. Відтак до неофіційних антропонімів можна включити атипові варіанти імен, прізвиськові утворення, особисті псевдоніми тощо. Вони, зазвичай, 
характеризуються необов'язковістю та додатковістю, водночас виконуючи, за М. Дуйчак, «номінативно-ідентифікаційно-диференційну функцію» $[12$, c. 256$]$.

Безперечно, базовою фундаментальною теорією для аналізу неофійних антропонімів $є$ номінативна теорія. Зокрема, Н. Шульська в рамках такої теорії визначає прізвисько як неофіційне найменування особи чи кількох осіб, яке дає інша людина, щоб підкреслити особливу домінантну рису, що відрізняє іменованого від інших, ідентифікує, конкретизує його, указує на домінування пейоративних конотащій. Фактично ці найменування О. Антонюк відносить до категорії вторинних антропонімічних номінацій, оскільки «прізвисько виникає на вторинному рівні, де одиничному об'єктові, що має вже як загальну назву, так і власну офіційну, присвоюється ще одне ім'я неофіційного характеру, яке задовольняє потреби у сфері мовлення» [13, с. 26]. Неофійні антропоніми політичного дискурсу містять значну частку імпліцитної інформації у вигляді семантичних імплікатур, оскільки їх поява, зазвичай, зумовлена політичним та соціальним контекстом, який складають певні прецендентні явища та фонові знання.

На приклад, неофіційні прізвиська колишнього президента США Дональда Tрампа охоплюють надзвичайно широкий ряд ономаністичних одиниць із різним оцінним, тобто конотативним значенням, починаючи від нейтрального «the Donald», політично вмотивованих «Mr Brexit» чи «The Indecider» - нерішучий (отримав під час заворушень за неспроможність прийняти швидке виважене рішення) до відверто пейоративних, тих що містять образливий та зневажливий зміст. Наприкінці свого перебування на посаді 45 президент США отримав ще одне прізвисько Mr Makes Matters Worse (Micmер Чим Далі - Тим Гірше), яке наочно відображало реальний стан справ Дональна Трампа та його провал на чергових виборах. За період своєї каденції 45-й президент США отримав чи не найбільшу кількість неофійних найменувань у формі прізвиськ (близько 300), установивши своєрідний антропонімічний рекорд [14]. Проаналізуємо найбільш уживані, виокремлюючи прагматичний контекст їх номінативного утворення, а саме:

1. Conspiracy Theorist-in-Chief (головний теоретик теорій змови) за його пристрасть просувати різні теорії змови;

2. President Snowflake (президент, Сніжинка / Крижинка), використання терміна snowflake уособлює його в'ялу прохолодну реакцію на критику, зокрема у Twitter;

3. Donald the Dove (Дональд Голуб миру) за його участь у проведенні мирних переговорів із Північною Кореєю, посередництві в припиненні 
вогню в Сирії, укладанні історичної угоди між Ізраїлем та ОАЕ й виведенні американських військ з Афганістану та Іраку;

4. Donald Drumpf - перекручена версія офіційного антропоніма, що вживається коміком Джоном Олівером у сегменті телесеріалу новин НВО, присвяченому Дональду Трампу;

5. President Tweety - термін, створений Байденом, що вказує на надзвичайне захоплення Трампа Твіттером;

6. Captain Chaos (капітан Хаoc) за однойменним відомим вигаданим персонажем коміксів через його схильність до безладу [15];

7. Donnybaby, Donnyboy, Donnybrook - іронічні зменшувально пестливі назви, які вказують на несерйозність поведінки, удавану грайливість та любов до шоу;

8. Trumpletoes (trample - топтати, tread on one's toes - зачіпати почуття, наступати на хворе місце) за його манеру ображати опонентів;

9. Tricky Trump (tricky - хитрий, лихий, підступний) за його особистісні якості та за аналогією з відомим прізвиськом 37-го президента США Річарда Ніксона Tricky Dicky;

10. Sociopathic 70-Year-Old Toddler, The Terroristic Man-Toddler найменування, які вказують на суперечливе поєднання рис інфантильності та соціально-агресивної поведінки [16].

Як бачимо, розглянуті неофіційні антропоніми Дональда Трампа містять семантичні імплікатури 3 різною конотативною оцінкою та фактично формують два протилежні портрети американського президента - позитивний і негативний. Прагматичною основою утворення таких найменувань стала екстралінгвальна інформація, що стосується особистісних характеристик номінанта, його способу життя, досягнень або, навпаки, провалів у політичній сфері, стратегій і тактик комунікативної поведінки.

Аналогічнну функціональну вмотивованість та прагматичне підгрунтя спостерігаємо й у випадках з іншими неофіційними антропонімами політичного дискурсу. Зокрема, чітко прослідковується наявність значної кількості неофіційних антропонімів політичного дискурсу, семантичним підтекстом яких $є$ психологічні риси характеру номінанта, позитивні та негативні, персональні особистісні характеристики. На приклад:

\section{Рональд Рейган}

The Great Communicator - відзнака надзвичайних комунікативних здібностей;

The Teflon President - семантична імплікація цього найменування полягає в тому, що до номінанта «не пристає» жодна негативна інформація, він залишається «чистим», незаплямованим в очах американців; 


\section{Барак Обама}

No Drama Obama - експлікується як той, що демонструє надзвичайно обережну, виважену поведінку, добре все планує, завжди залишається спокійним та розважливим;

\section{Джко Байден}

Sleepy Joe - пейоративний антропонім, який указує на повільність та ментальну заторможеність номінанта, його нездатність швидко мислити й реагувати;

Особливу групу становлять неофіційні антропоніми, причиною утворення яких була політична діяльність номінантів. Семантичною імплікацією цих найменувань $\epsilon$ екстралінгвальна інформація, що стосується певної політичної події національного чи міжнародного рівня, політичного курсу номінанта, його вподобань, результатів виборчих компаній, політичних здобутків та провалів - усе, що можна сукупно назвати результатами політичної діяльності. Для ілюстрації:

\section{Барак Обама}

Deporter in Chief (Головний депортувальник) - прізвисько, яке стало результатом імміграційної політики Барака Обами, який за часів своєї адміністрації депортував понад 2 мільйони нелегальних іммігрантів, більше ніж будь-хто з його попередників;

\section{Маттео Ренці}

The Scrapper (Чистильник) - неофіційний антропонім італійського прем'єр-міністра, зусилля якого були спрямовані на реформування та оновлення політичної системи країни;

\section{Володимир Путін}

Puppet Master (Ляльковод/Лялькар) - прізвисько 3 негативною семантичною конотацією, що акцентує на схильності номінанта до маніпуляційних процесів у політиці, здійсненні тиску, утручання у внутрішні справи інших держав, зокрема виборчі процеси;

\section{Ангела Меркель}

Mutti або Mommy (Мамуся) - неофійне найменування канцлера Hiмеччини згенероване спочатку як образливе прізвисько, але в подальшому було підтримане виборцями та набуло позитивної семантичної імплікації, характеризуючи Ангелу Меркель як державного лідера, який надзичайно добре дбає про інтереси країни та ії громадян [15].

Як демонструють наведені вище приклади, неофійні антропоніми політичного дискурсу відзеркалюють семантичні імплікатури, що стосуються, передусім, персональних рис характеру номінантів й особливостей їхньої політичної діяльності та її наслідків. 


\section{3. ВИСНОВКИ ТА ПЕРСПЕКТИВИ ПОДАЛЬШИХ ДОСЛІДЖЕНЬ}

Підсумовуючи викладене вище, можемо констатувати, що політичний дискурс унаслідок своєї комунікативної спрямованості та прагматичної вмотивованості поряд 3 експліцитним змістом містить значну частку імплітитної інформації, яка значно розширює та доповнює його інформаційне поле. Така імпліцитна інформація включає цілу низку неконститутивних елементів у вигляді фонових знань, пресупозиційної інформації, конверсаційних і неконверсаційних імплікатур, семантичних імплікатур окремих лексичних одиниць, зокрема офіційних та неофіційних антропонімів політичного дискурсу. Останні підпадають, відповідно, під категорії одиниць первинної й вторинної номінації, що визначає різні підходи до їх вивчення та шляхи інтерпретації семантичних імплікатур, які вони ретранслюють. Відтак під час дослідження офіційних найменувань політичних лідерів дієвим уважаємо етимологічний і семасіологічний підходи, що дає змогу прослідкувати походження ономастичної одиниці та виокремити імпліцитні семантичні елементи шляхом аналізу значення його дериваційних складників. Такі семантичні імплікатури, зазвичай, $\epsilon$ безвідносними до особистості номінанта, незалежними та персонально невмотивованими, часто містять нейтральну фонову інформацію. Водночас варто зауважити, що вони дивним чином корелюються з індивідуальними характеристиками політичних лідерів та особливостями їхньої політичної діяльності. Загалом, вони формують цілісне семантичне значення антропоніма.

У випадку дослідження неофіційних антропонімів політичного дискурсу найбільш ефективним вважаємо застосування прагматичного підходу, оскільки поява таких найменувань зумовлена екстралінгвальним контекстом, є соціально та політично вмотивованими. Напротивагу згаданим імпліцитним елементам, семантичні імплікатури неофіційних найменувань є особистісно прив'язаними, прагматично й функціонально вмотивованими, містять позитивну та негативну конотації й у гіперболізованому вигляді вказують на характерні риси номінанта та особливості його політичної діяльності.

Перспективи подальших досліджень становить категоризація семантичних імплікатур офіційних і неофіційних антропонімів політичного дискурсу за їх прагматичною та функціональною спрямованістю. Доцільним також вважаємо здійснення комплексного аналізу імпліцитного змісту політичного дискурсу 3 виокремленням i ранжуванням усіх неконститутивних елементів та їх комунікативної ваги у формуванні цілісної змістової ментальної моделі дискурсу. 


\section{СПИСОК ВИКОРИСТАНИХ ДЖЕРЕЛ}

1. Сотніков, А. В. (2012). Нарис сучасних досліджень політичного дискурсу: лінгвістичний аспект. Вісник Дніпропетровського університету імені Альфреда Нобеля. Серія «Філологічні науки», № 1 (3), с. 186-191.

2. Даниленко, О. В. (2016). Семантичні особливості антропонімів діячів КиєвоМогилянської академії XVII-XVIII ст. Магістеріум, вип. 62. Мовознавчі студії, с. 21-27.

3. Ніколенко, О. В. (2018). Прізвиська як соціокультурні символи. Young Scientist, вип. 2 (54), с. 209-212.

4. Павлюк, В. А. (2014). Лінгвістичний статус прізвиська та його місце в антропонімії. Наукові записки Вінницького державного педагогічного університету імені Михайла Кочюбинського. Філологія (мовознавство): зб. наук. праць / голов. ред. Н. Л. Іваницька. Вінниця: ТОВ «Фірма «Планер», вип. 19, с. 157-162.

5. Trump. Multitran. URL: https://www.multitran.com/m.exe?11=1\&12=2\&s=trump

6. Mysteries of Russia's ancient past: Where did the surnames Romanov, Putin, and Lenin originate? URL: https:/www.rbth.com/history/327182-russian-names-putin-romanov-lenin

7. Пороша. Публічний електронний словник української мови. URL: http://ukrlit. org/slovnyk/porosha

8. Порошенко - карта і походження прізвища. Ridni. URL: https://ridni.org/karta/\% D0\%BF\%D0\%BE\%D1\%80\%D0\%BE\%D1\%88\%D0\%B5\%D0\%BD $\%$ D0\%BA\%D0\%BE

9. Происхождение фамилии Зеленский. URL: http://www.ufolog.ru/names/order/\% D0\%97\%D0\%B5\%D0\%BB $\%$ D0\%B5\%D0\%BD $\%$ D $1 \% 81 \% \mathrm{D} 0 \% \mathrm{BA} \% \mathrm{D} 0 \% \mathrm{~B} 8 \% \mathrm{D} 0 \% \mathrm{~B} 9$

10. Bide. Merriam-Webster. URL: https:/www.merriam-webster.com/dictionary/bide

11. Наливайко, М. Я. (2011). Неофіційна антропонімія Львівщини: дис. ... канд. філол. наук: 10.02.01 - українська мова. Тернопіль, 201 с.

12. Дуйчак, М. (1994). Прізвиська та їх мотивація. Проблеми сучасної ареології. Київ. Наук. думка, с. 256-259.

13. Антонюк, О. В. (2011). Сучасні прізвиська Донеччини (семантика і структура): дис. ... канд. філол. наук: 10.02.01 - українська мова. Донецьк, 296 с.

14. Ranked: World Leaders With the Best Nicknames. URL: https://www.theatlantic. com/international/archive/2016/11/ranked-world-leaders-with-the-best-nicknames/508154

15. List of nicknames of the presidents of the United States. Wikipedia. URL: https:// en.wikipedia.org/wiki/List_of_nicknames_of_presidents_of_the_United_States\#Donald_ Trump

16. Ненашева, T., Меркулова, Э. Сколько имен у Дональда Tрампа. URL: https:// iq.hse.ru/news/200319000.html

\section{INTERPRETATION OF POLITICAL DISCOURSE ANTHROPONYMS IMPLICIT SEMANTICS}

The article studies the implicit aspect of political discourse through the analysis of semantic implicatures of anthroponyms. The latter ones include formal (names, surnames) and informal (nicknames, aliases, pseudonyms) nominative units of famous politicians, heads of state and governments which respectively fall into categories of primary and secondary nomination. This 
fact determines different approaches to their study and ways of interpreting semantic implicatures they reproduce. It has been determined that the etymological and semasiological approaches are considered the most effective in the research of political leaders' formal names. They make it possible to trace the origin of a particular anthroponym and to identify implicit semantic elements by analyzing the meaning of their derivative components. The semantic meaning of such onomastic units is specific: it does not reflect concepts, but just indicates the original semantics - the motives of nomination. Such semantic implicatures, as a rule, are irrelevant to the nominee's personality, individually unmotivated and frequently contain neutral extralingual information. At the same time, they are constituent elements of anthroponym's integral semantic meaning.

The pragmatic approach has proved efficient in dealing with informal anthroponyms in political discourse as it is extralingual factors that pragmatically and functionally prompt the formation of nicknames and other informal nominative units. The research demonstrates that the semantic implicatures of such informal names contain both positive and negative connotations and in an exaggerated form indicate the characteristics of a nominee, distinguish him from others, convey information about the peculiarities and highlights of his political career.

Key words: political discourse, nomination, formal anthroponym, informal anthroponym, nickname, semantic implicature.

\section{REFERENCES}

1. Sotnikov, A. V. (2012). Essay on modern research of political discourse: Linguistic aspect. Bulletin of Dnipropetrovsk University named after Alfred Nobel. Philological Sciences Series, 1 (3), 2012, 186-191.

2. Danylenko, O. V. (2016). Semantic features of anthroponyms of figures of KyivMohyla Academy of XVII-XVIII centuries. Magisterium, 62, Linguistic Studies, 21-27.

3. Nikolenko, O. V. (2018). Nicknames as socio-cultural symbols. Young Scientist, 2 (54), 209-212.

4.Pavliuk, V. A. (2014). Linguistic status of the nickname and its place in anthroponymy. Scientific Records of Vinnytsia State Pedagogical University named after Mykhailo Kotsyubynsky. Series: Philology (Linguistics): collection of scientific papers. Vinnytsia: LLC «Firm»«Planer», 19, 157-162.

5. Trump. Multitran. URL: https://www.multitran.com $/ \mathrm{m}$. exe $? 11=1 \& 12=2 \& \mathrm{~s}=$ trump

6. Mysteries of Russia's ancient past: Where did the surnames Romanov, Putin, and Lenin originate? URL: https://www.rbth.com/history/327182-russian-names-putin-romanov-lenin

7. Porosha. Public electronic dictionary of the Ukrainian language. URL: http://ukrlit. org/slovnyk/porosha

8. Poroshenko - map and origin of the name. Ridni. URL: https://ridni.org/karta/\%D0 \%BF\%D0\%BE\%D1\%80\%D0\%BE\%D1\%88\%D0\%B5\%D0\%BD\%D0\%BA\%D0\%BE 
9. Origin of the name Zelenskyi. URL: http://www.ufolog.ru/names/order/\%D0\%97\% D0\%B5\%D0\%BB\%D0\%B5\%D0\%BD $\%$ D1\%81\%D0\%BA\%D0\%B8\%D0\%B9

10. Bide. Merriam-Webster. URL: https://www.merriam-webster.com/dictionary/bide

11. Nalyvaiko, M. Ya. (2011). Informal anthroponymy of Lviv region: Thesis for a Candidate Degree in Philology: 10.02.01 - Ukrainian language. Ternopil, 201 p.

12. Duichak, M. (1994). Nicknames and their motivation. Modern areology issues. Kyiv: Nauk. dumka, 256-259.

13. Antoniuk, O. V. (2011). Modern nicknames of Donetsk region (semantics and structure): Thesis for a Candidate Degree in Philology: 10.02.01 - Ukrainian language. Donetsk, $296 \mathrm{p}$.

14. Ranked: World Leaders With the Best Nicknames. URL: https://www.theatlantic. com/international/archive/2016/11/ranked-world-leaders-with-the-best-nicknames/508154

Матеріал надіймов до редакиіï 16.01.2021 p.

УДК 341.176:061.1€С+004

\section{Олена Пістракевич,}

кандидат наук з державного управління,

старший викладач кафедри міжнародних відносин та міжнародного права, Київський університет імені Бориса Грінченка,

ORCID ID 0000-0003-0457-1954

o.pistrakevych@kubg.edu.ua

DOI 10.29038/2524-2679-2021-01-160-174

\section{СТРАТЕГІЇ РОЗВИТКУ ШТУЧНОГО ІНТЕЛЕКТУ В ЄВРОПЕЙСЬКОМУ СОЮЗІ (НА ПРИКЛАДІ КРАЇН ВИШЕГРАДСЬКОЇ ГРУПИ)}

У статті досліджено національні стратегіï розвитку штучного інтелекту в країнах Вишеградської групи, прийняті за рекомендаціями Свропейської комісї в контексті Стратегї розвитку итучного інтелекту в СС. У 2018 р. Свропейська комісія на конференції Digital Day 2018 об'єднала міністрів та представників країн СС для заохочення співпраці в галузі штучного інтелекту, блокчейну, охорони здоров'я $\check{u}$ інновацій, спираючись на прогрес, досягнутий на иляху створення єдиного ичифрового ринку, на якій, зокрема, європейські краӥни підписали Декларацію про співробітництвво в галузі штучного інтелекту. Польщьа, Чехія, Угорщฺина та Словаччина прийняли спільну позищію

(C) Пістракевич О., 2021 